\title{
Grapevine Propagation Method with Two Temperature Controlling Process
}

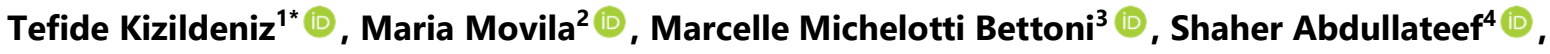 Serkan Candar ${ }^{5}$}

${ }^{1}$ Niğde Ömer Halisdemir University, Faculty of Agricultural Sciences and Technologies, Biosystem Engineering Department, 51240, Niğde, Turkey

${ }^{2}$ Navarra University, Department of Environmental Biology, Pamplona, Spain

${ }^{3}$ Universidade Tuiuti do Paraná, Curitiba-PR, Brasil

${ }^{4}$ Syrian Academic Expertise, Food Security and Sustainable Development Research Department, Gaziantep, Turkey

${ }^{5}$ Tekirdag Viticulture Research Institute, Tekirdağ, Turkey

How to cite: Kizildeniz, T., Movila, M., Bettoni, M. M., Abdullateef, S., \& Candar, S. (2022). Grapevine propagation method with two temperature controlling process. Viticulture Studies (VIS), 2(1): 45 - 53. https://doi.org/10.52001/vis.2022.10.45.53

\section{Article History:}

Received: 19.12 .2021

Accepted: 19.01 .2022

First online: 26.01.2022

\section{Corresponding Author}

tkizildeniz@ohu.edu.tr

\author{
Keywords \\ Vitis vinifera $\mathrm{L}$ \\ Grapevine cuttings \\ Temperature control \\ Cutting rooting system \\ Growing media
}

\section{Introduction}

There've been several instances of failures of young vines and the initial collapse of a new vineyard since in the 1990s' in global vine growing boom (Aigoun-Mouhous et al., 2021). In the last 30 years, the mondial wine business has considerably transformed (Beccaria and Pretto, 2021). It has evolved from a quite small, locally oriented, family business with a European emphasis to a considerably more international industry controlled by international firms (Pomarici et al., 2021). As requirement of being international firms, there is now a greater emphasis on quality management and standardization on grapevine establishment and vegetative vine propagation (Aylward, 2005).

\begin{abstract}
Aine propagation methods can cause physiological stress, it has a manage the applied techniques in decreasing the time period ar manipulating the temperature of two nodes of the same cuttings in orde to stimulate roots and inhibit shoot formation for vegetative propagation. To avoid mold and other bacterial diseases, antifungal and antibacterial treatment is applied. In asymptomatic situations, all cuttings should be treated with hot water before carrying out the rooting process. The soilless aseptic hydrated media to maintain Meanwhile, spatial temperature under $1{ }^{\circ} \mathrm{C}$ may result in chilly system must above $4^{\circ} \mathrm{C}$ stimulate microbial activity. Therefore, th viticulture farmers for regulation of root development and disease-free cuttings in a short time period.
\end{abstract}

Nevertheless, the case of the Turkish viticulture and wine industry has a different story. According to Ottoman archives, Central Anatolia is known for its rich viticulture and production of wine, by equally, large local Christian populations and villages of Muslims participating in such industries (Balta, 2017). The intensive vine growing was mainly handled by non-Muslim communities in Ottoman Empire until barter agreements during the split of Empire. When these farmers who were intensively cultivated grapevines, left the country, their knowledge of vine cultivation were also somehow lost. This has led to loss of several native grapevine's varieties due to lack of knowledge on cultivation. The changes in the grapevine industry mentioned above in Europe have also affected grapevine 
cultivation in Turkey in recent years, since Europe is the primary export market for Turkey. This has caused to search lost grapevine varieties to start to cultivate again in Anatolia region (Kizildeniz, unpublished data).

On the other hand, finer wines are currently producing in regions where grapes are planted in some exceedingly challenging climates and surroundings where is few or no tradition of wine production and drinking (Mahenge, 2020). Nevertheless, the grapevine sapling production sector has not encountered the same level of transformation. It is still mostly controlled by small-size and mid-size household enterprises and cooperatives, and though development into modernizing has allowed nurseries to expand production, the quality of crop varieties isn't absolutely outstanding (Lwelamira et al., 2015; Mahenge, 2020). As far as lately, there were limited formal values or evaluation standards aimed at grapevine materials, besides cultivar and root-stock selection, additional crucial planting material features were not always properly considered by nurseries and grape farmers (Romeo-Olivan et al., 2021). Hereby, unsuccessful vineyard plantings are seen in different viticulture regions due to the use of non-standard saplings. These vineyards must be established again within five to ten years of initial planting (Smart et al., 2012; Moretti et al., 2021). Most of those unsuccessful or inefficient vines were discovered to be diseased with microorganisms that cause trunk illness such as Phomopsis dieback, Esca complext, Botryosphaeria dieback, and Eutypa dieback or even additional visual abnormalities that impacted growth, vitality, and durability (Stamp, 2001; Waite et al., 2015; Sosnowski et al., 2021).

Losses resulting from the unsuccessful or insufficient establishment and decrease of freshly planted vines are already considerable. The responsibility for poor quality saplings, which is underestimated during the selection of vegetative material for planting, is usually be in charge of sapling producers. (Komínek and Holleinová, 2003; Waite and Morton, 2007; Rego et al., 2009; Gramaje and Armengol, 2011; Whitelaw-Weckert et al., 2013). Moreover, here is also an increasing understanding of the effect of dormant stem illnesses and additional abnormalities on young vines (Morton, 2012;
Smart et al., 2012; Smart, 2013) and the quality of planting material is increasingly shifting more broadly into the wine sector focus. This has encouraged the establishment of a detailed standard in Australia (Standards Australia, 2013), and as a consequence, the efficiency of propagation and planting materials is projected to vastly increase. Even though, the standards are currently in place in various countries, they do not detailed enough or implemented via complete practice guidelines. As a result, substandard material occasionally passes the examination.

The propagation of grapevine is very simple, but it takes both expertise and organization to generate the millions of highquality vines required each year throughout the world for young plants and replanting to contaminated and/or unprofitable vineyards. Grapevine propagation methods are varied such as in vitro propagation (Barlass et al., 1982), pitch grafting of rooted root-stock cutting (Alley, 1957), and softwood cuttings (Warmund et al., 1986).

To accommodate the high demand stemming from the rise of the wine industry, contemporary grapevine sapling production centers, similar to industrial factories, have developed, where workers are single-task in optimized production units. In spite of significant progress toward modernization (Borsellino et al., 2012), the most key obstacle continues nurseries' capacity to ensure a sustainable supply of safe, healthy, and consistent vines. This would need full explanations of the techniques used to produce high-quality cuttings and vines, as well as effective evaluation quality criteria for cuttings and completed vines.

Here this review describes the modern vine propagation system applied fully and/or semi auto-controlled two different temperatures in the same cuttings under soilless media treated in vertical farming methods with selection criteria for vine propagation materials.

\section{High Quality Vine Cuttings Characteristics}

The main features of quality grapevine sapling are accurate identification, excellent health, durability and physiological ability. Confirmed saplings of clones and cultivars should be grown free of severe viruses and plant 
disease infections to maintain their physical capacity (Nicholas et al., 1992). Quality vine saplings must also be uninjured, have optimal plant geometry and well-formed graft combinations. Quality grapevine saplings from a quality nursery grow rapidly and respond well in the vineyard. When vine saplings to be used in vineyard planting are leafless, it is difficult to identify clones and cultivars. Also, the effects of stress and latent invasions are not immediately apparent. However, a visual inspection can be done to determine sapling quality. Mother vine maintenance, harvesting and pruning procedures have a significant influence on the superiority and physical capability of vine cutting and sapling. The resistant rootstocks have allowed the trade to thrive and endure (Bisson et al., 2002). As growing improperly identified vines could have substantial financial implications, germplasm and maternal collection of vines have indeed developed in the majority of grapevine producers (Laucou et al., 2011). These essential collections were created to provide propagators with verified, authentic cuttings which are also virus-free. They are frequently examined for mistaken vines and viral outbreaks. The propagation options that have resulted from them have been crucial in diminishing the impact of grapevine viral diseases and the challenges due to misdiagnosed vines on the business. Furthermore, certification does not all the time imply physiological competence or the absence of diseases and physical anomalies in the plants (Chien and Golino, 2006). Additionally, usage of specialized cutting is not standard, especially after the availability of certified material exceeds the need for cuttings (Waite et al., 2015).

According to Stamp (2001), the partial graft recovery is in $13 \%$ of vines and poor scarce roots, $4 \%$ of rootstock rootling and $9 \%$ of transplanted vines after evaluating various seemingly sound and healthy transplanting materials provided by a variety of nurseries. Poor, underdeveloped vines and rootstock rootlings made about 3 and $8 \%$ of the total, respectively. Consequently, $35 \%$ of rootstock rootling and $39 \%$ of grafted grapevines were found to be faulty. Vine stock with substantial flaws, such like graft unions that are smaller than $80 \%$ recovered or cuts on roots and trunks, is probably to function as expected in the vineyard and nursery. Small flaws, like graft mergers which are from 80 to $100 \%$ recovered, or scarce, irregularly distributed root, could be adequate, nonetheless the collective influence of multiple slight flaws is a significant factor when considering the associated risks with these kinds of material (Stamp, 2001).

\section{Disease- Free Cuttings Materials}

The cuttings are harvested and transported from the parental vine block to the propagation center as the first phase in the multiplication process. Pruning and harvesting procedures in mother vine blocks must be well maintained to provide the quality of cutting (Daughtrey and Benson, 2005). Cutting that are kept on vineyards' surfaces are vulnerable to desiccation, infestation by soil borne pathogens, and hoarfrost injury. In cases where transport to the nursery takes longer than a few days, desiccation increases the risk of damage by hypoxia and temperature extremes. Whenever the temp of winter increases over 2 to $4{ }^{\circ} \mathrm{C}$, the material's respiration degree rises, as well. The accessible $\mathrm{O}_{2}$ in packing is soon depleted, and metabolic heating or the metabolites of fermentative respiration are incapable to disperse, jeopardizing the cutting survivability.

It is necessary to avoid mold and other bacterial diseases formation on cuttings that have previously been treated in antifungal and antibacterial dip or spray as integrated pest management (IPM). In asymptomatic situations, all cuttings should be treated with hot water before being used to cure various trunk diseases. Cuttings that may not be going to be treated right away could be kept inside a tidy, cool environment at $1-2{ }^{\circ} \mathrm{C}$ in tidy wrapping with multiple tiny, 7-10 $\mathrm{mm}$ well-spaced holes which permit air to enter the cutting deprived of risk of desiccation. In order to avoid mold growing on cuttings in cold packing, cutting was before treated with a briefly fungicidal dip or spray, dried well and saved in storage. Freezing can induce physiological stress in storage temperatures under $1{ }^{\circ} \mathrm{C}$, and uncontrolled temperature variations exceeding $2{ }^{\circ} \mathrm{C}$ may have a detrimental influence on the quality of cutting (Hartmann and Kester, 1990). When storing temperature increases above $4{ }^{\circ} \mathrm{C}$, microorganisms spread; as a trigger of fermentative respiration, elevated metabolic activities of the cutting create heat, exhausts existing $\mathrm{O}_{2}$ (Becker 
and Hiller, 1977). If vine materials are kept with climacteric fruits like pears and apples, additional types of stress in cold storing involve changes in metabolic ratio produced by transferring vine material into or out of preservation, along with being subjected to increased amounts of ethylene (Pierik et al., 2006).

\section{Hot Water Treatment}

In asymptomatic situations, all cuttings should be treated with hot water before being used to cure various trunk diseases. Since the 1990s, the wine industry has been affected by sporadic early grapevine deaths and the growing problem of non-standard grapevine production material. Hot water treatment (HWT) is applied on dormant cuttings with hot water at $50{ }^{\circ} \mathrm{C}$ for $30 \mathrm{~min}$ to remove first of Phaeomoniella chlamydospora and also other endogenous pathogens that cause mortal losses in vineyard (Figure 1). HWT is found to promote a temporary changeover to fermentative respiration and initial growth retardation in exposed material, even though the impacts of HWT on vines are not entirely explored. Vine loss has also been related to low nursery sanitation, as well as inadequate packaging and storage procedures during propagation and transplanting (Waite and Morton, 2007).

\section{Ozonated Water Treatment}

Grapevine trunk pathogens can contaminate the grapevine nursery at various phases of plant development. As above mentioned, hot water treatment is one way to eliminate these disease factors especially for Phaeomoniella chlamydospora. There is another method that applies ozone water treatment for Phaeoacremonium minimum and Phaeomoniella chlamydospora as well. With this method, aqueous ozone totally stopped spore germination in vitro. Fungal development in vines was inhibited six weeks after contamination. In the vine nurseries, ozone therapy was equivalent to standard chemical application. Aqueous ozone watering demonstrated no adverse impact on vines development (Figure 1). Due to its antifungal qualities and lack of phytotoxicity, ozone treatment is one of the possible alternative for managing disease control in nurseries (RomeoOlivan et al., 2021).

\section{Best Practices Case: Soilless Two Temperature Treatment on Vine Cutting Propagation}

\section{Cuttings Selection from Mother Vine}

Vine cuttings must have at least three buds (or nodes); the primary, secondary, and tertiary bud. The tertiary node is exposed to IBA

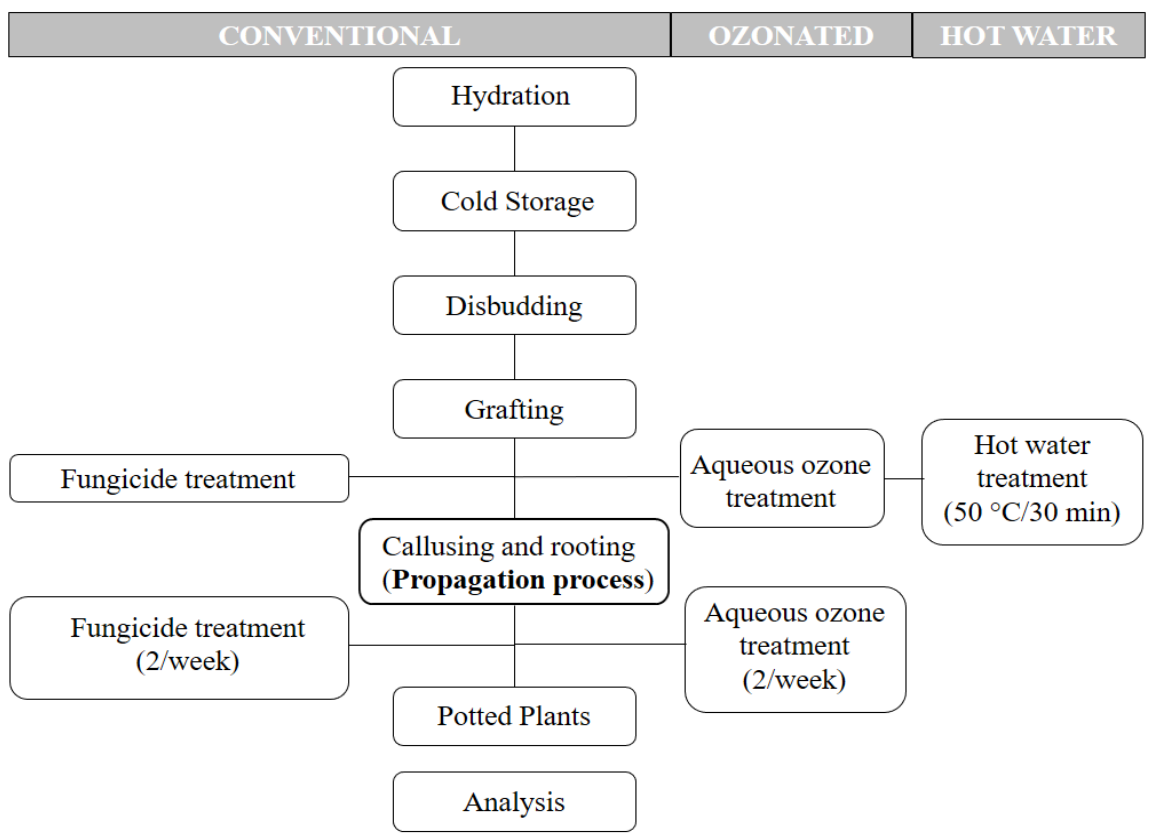

Figure 1. The most successful disease- free cuttings propagation methods comparison. 
treatment (not always) and then exposed to soilless aseptic hydrated media to maintain thermal isolation between the root and the emergence of root callus from the tertiary node to the primary node (Santa María Monasterio, 2005).

\section{Media Selection}

Cuttings are typically put into hygienic containers holding a moist but just not wet and no nutrient solution (to force capacity of cuttings for adaptation), sterile media such as perlite or vermiculite. The callusing media can be any as mentioned above, however in the case of controlling two different temperatures in the same cuttings the media should be thermal insulating such as glass wool and rock wool (Santa María Monasterio, 2005; Kizildeniz et al., 2015).

\section{Integrated Pest Management and Rooting Hormone Treatment}

It is essential to apply a brief fungicidal dip or spray and dry well to avoid mold growing on cuttings or avoid any existed disease transmitted by the mother vine. The material's fundamental regeneration capability is impacted by physiological competence. Lower remarkable ratios of cuttings rooting process are associated persistently maximum rates of abscisic acid (ABA) and gibberellic acid (GA) plant hormones in several rootstock cultivars, notably Vitis berlandieri hybrids. Hormonal changes in cuttings naturally fluctuate over time. Cuttings growing is frequently more effective if they are treated with above mentioned hormones later in the inactive season compared to half or earlier of winter (Alley, 1979; Nicholas et al., 1992). Delaying treatment is not usually practicable in large nurseries, where hundreds of cuttings are produced over a lengthy season. Furthermore, rooting can be stimulated deprived of soaking, like, by applying artificial auxins in the indolebutyric acid (IBA) version to depends on cutting that are difficult-to-root like $V$. berlandieri hybrid rootstocks (Nicholas et al., 1992). IBA treatment for rooting has a slight effect on the varieties that are easily rooted (Nicholas et al., 1992) and grapevine cuttings ( $V$. vinifera) are smoothly generated to root so the rooting hormones are rarely applied that is the case of the securing 100\% rooting (Kizildeniz et al., 2015). According to Kizildeniz et al. (2015; 2018a; 2018b), cuttings of $V$. vinifera L. was selected to only three nodes and at the last node was treated to IBA as explained in Mullins (1966) and Santa María Monasterio (2005). These cuttings were maintained humid in a cold room $\left(4{ }^{\circ} \mathrm{C}\right.$ ) until callus and root formation ( 3 to 4 weeks) and then the rooted-cuttings were transplanted. Keeping the IBA treated-last nodes under the temperatures of $25-27{ }^{\circ} \mathrm{C}$ stimulates callusing and rooting formation while keeping moisture in a cold room under $5^{\circ} \mathrm{C}$ is allowing to maintained dormant stage of the cuttings for increasing future field adaptation with strong roots and providing the natural hormonal balance of cuttings. This also allows us to obtaining fast rooted cuttings with high success.

\section{Different Temperature Controlling for Callus/Root and No-Budbreaking}

Callusing occurs at a slower rate at 26-27 ${ }^{\circ} \mathrm{C}$ temperatures, although slower forming callus produces the most robust union than quicker growing callus $\left(28-29{ }^{\circ} \mathrm{C}\right)$. Insufficient callus tissue could develop whether cutting kept in the callusing trays for longer than three weeks, preventing the growth of new phloem and xylem all over the graft union. Callus tissue must not extend more than 2-3 $\mathrm{mm}$ from the graft union (Hartmann and Kester, 1990). Temperature exceeding $29{ }^{\circ} \mathrm{C}$, or high-density storage of cutting, can limit metabolic heat debauchery, which can be lethal to the cuttings.

Callused cuttings must be handled with minimizing losses or development limitations induced by shocks transplanting. Cutting is susceptible to desiccation till roots develop, thus hardening (acclimating) the buds of callused cuttings before planting them in pots or a field may be advantageous. Toughening could be achieved by eliminating the peak few $\mathrm{cm}$ of the callusing environment to treat the buds and graft unions and storing the callusing trays in a well illuminated but controlled conditions for two or three days (Nicholas et al., 1992). To avoid drying, tips of cutting could be coated covered with a thin coating of graft paraffin if the graft union and buds have not previously been paraffined (Nicholas et al., 1992). Unless the 


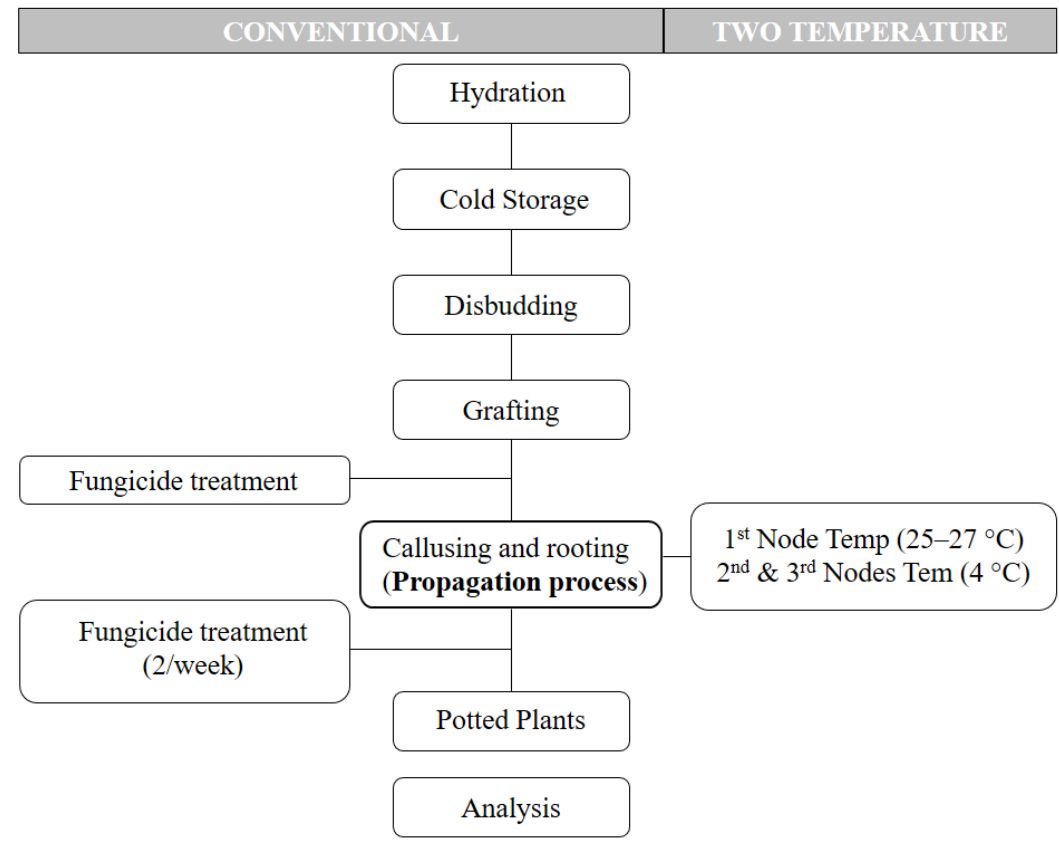

Figure 2. Comparison of conventional and two temperature controlling vine cuttings propagation methods.

callused-cuttings are transplanted immediately into a field nursery, the grafting paraffin also can apply and able to supply for some prevention of freezing. Furthermore, intensively thick paraffin application is undesired (Hartmann and Kester, 1990). On the other hand, considering the plant physiology, waxing with paraffin is preventing cuttings from bud-breaking. The competence of bud-break, - that is frequently determined, while to bud break in forcing condition,- has been used to assess, if buds are endo dormant, para dormant, or eco dormant in fruit tree species (Yamane, 2014; Balandier et al., 1993a; 1993b; Fan et al., 2010; Kitamura et al., 2018). When the cuttings were exposed to callusing/rooting conditions $\left(25-27^{\circ} \mathrm{C}\right)$, the vegetative cuttings were also exposed to forcing conditions (as being to exposure under $15^{\circ} \mathrm{C}$ ) (Yamane et al., 2019). However, while the temperature is the trigger for bud-breaking and hormonal changes are already started, the applied waxing (no matter the purpose) is preventing from budbreaking. This may cause the adaptation and success of the cuttings in the field. Therefore, in the same cuttings, two temperature degrees are needed to be applied for callusing and preventing bud-breaking, not with waxing.

The cuttings were forced to have callus/roots and meanwhile forced themselves to have buds and shoots in the conventional vegetative propagation methods. This can cause less success and adaptation in the field conditions. However, if the cuttings are only forcing to have strong callus and root formation, not forcing to have shoots meanwhile, this leads to increase the success of cuttings and best adaptation in the field. Therefore, in sterile thermal isolated media such as rock wool or glass wool, supplying $25-27^{\circ} \mathrm{C}$ during $2-3$ weeks for callus and root development in an environment at $4{ }^{\circ} \mathrm{C}$ for inhibiting to budbreaking (Santa María Monasterio, 2005). When the cutting formed the callus, transplantation takes place to the pots containing media with no nutritional source for forcing cuttings to obtain their sources of shoots for increasing adaptation during an additional week (or 2 weeks) in the greenhouse until bud-breaking (Figure 2).

\section{Conclusion}

Now it is apparent that the performance of grapevine propagation and the survival of the emerging vines are reliant on plenty of parameters, ranging from the maintenance of the mother vines to the emergence of modern vines in the vineyard. It has now obvious that the effectiveness of propagation is dependent on the use of best practices at all stages of the propagation cycle. Cutting and vine failures are largely a consequence of a transition of significant, but relatively modest, and as 
accumulation damages. The implications of these are not acknowledged as negative.

On the other hand, the impacts of the growing environment and nursery procedures on propagating material, which is fundamentally changeable, and so can not anticipate the result of any particular propagation cycle with total accuracy, is not yet completely understood. Outcomes of the initial studies into the physiological response of cuttings and rooted vines to different protocols have yet to determine the variables that regulate the sensitivity of grapevine propagating material to propagation methods, and in this sense, there are more work still waiting to be done. In traditional rooting process is generally applied under 26-27 ${ }^{\circ} \mathrm{C}$ temperature conditions. However, this can also be a trigger for shooting formation as well. To suppress the shooting and protection of the other microbial factors, paraffinized was applied on the $3^{\text {rd }}$ and sometimes $2^{\text {nd }}$ nodes, while the cuttings have force conditions to obtain shoots under 25-27 ${ }^{\circ} \mathrm{C}$. Yet, the physiological mechanism is not well known but apparently the cuttings obtaining the roots without shooting but the percentage of the success in the field adaptation is becoming low. Therefore, alternatively and obviously controlling two different temperature forcing conditions in the same cuttings for rooting (25$27{ }^{\circ} \mathrm{C}$ ) and suppressing the bud-breaking and shoot formation $\left(4^{\circ} \mathrm{C}\right)$ is becoming more parallel to cutting physiology and increasing the adaptation possibility in the field. In this way, the cuttings will not force their limited sources at the same time for both rooting/callusing and budbreaking/shooting formation and this demonstrates the increase of field adaptation to propagated cuttings in the long term.

\section{Acknowledgments}

The authors appreciated the support provided by Sigfrido Romeo, Agriculture Engineer, Fatih Sencer Akça and Ayşenur Arslan and acknowledge the great viticultural techniques were taught by PhD supervisors of authors (TK and MM); Dr. Juan Jose Irıgoyen, Dr. Mari Carmen Antolin from Universidad de Navarra, Plant Stress Physiology Group and Dr. Fermin Morales from Institutode Agrobiotecnología, CSIC.

\section{Ethical Approval}

Ethical approval was not required for this study.

\section{Conflicts of Interest}

Authors declare no competing interests exist.

\section{Author Contribution}

TK, MM, and SC planned the general disposition of manuscript. TK, MM, MMB, SA, and SC made critical revision of the manuscript for intellectual content. TK contributed to the revision and elaborated the final manuscript. All authors read and approved the final manuscript.

\section{References}

Aigoun-Mouhous, W., Mahamedi, A. E., León, M., Chaouia, C., Zitouni, A., Barankova, K., Eichmeier, A., Armengol, J., Gramaje, D., \& Berraf-Tebbal, A. (2021). Cadophora sabaouae sp. nov. and Phaeoacremonium species associated with Petri disease on grapevine propagation material and young grapevines in Algeria. Plant Disease, PDIS-11. https://doi.org/10.1094/PDIS-11-20-2380-RE

Alley, C. (1957). Mechanized grape grafting: Portable machine developed for bench or field grafting of grapes saves time and eliminates the need for skilled labor. California Agriculture, 11(6), 3-12.

Alley, C. J. (1979). Grapevine propagation. XI. Rooting of cuttings: Effects of indolebutyric acid (IBA) and refrigeration on rooting. American Journal of Enology and Viticulture, 30(1), 28-32.

Aylward, D. (2005). Global Landscapes: A speculative assessment of emerging organizational structures within the international wine industry. Prometheus, 23(4), 421-436. https://doi.org/10.1080/08109020500350260

Balandier, P., Bonhomme, M., Rageau, R., Capitan, F., \& Parisot, E. (1993a). Leaf bud endodormancy release in peach trees: evaluation of temperature models in temperate and tropical climates. Agricultural and Forest Meteorology, 67(1-2), 95-113. https://doi.org/10.1016/0168-1923(93)90052-J

Balandier, P., Gendraud, M., Rageau, R., Bonhomme, M., Richard, J. P., \& Parisot, E. (1993b). Bud break delay on single node cuttings and bud capacity for nucleotide accumulation as parameters for endo- and 
paradormancy in peach trees in a tropical climate. Scientia Horticulturae, 55(3-4), $249-261$. https://doi.org/10.1016/0304-4238(93)90036-P

Balta, E. (2017). "From Ypolenion to Bolum: The Viticultural Transition in Cappadocia through Ottoman Sources and Oral Tradition", in: Of Vines and Wines The Production and Consumption of Wine in Anatolian Civilizations through the Ages, Ancient Near Eastern Studies Suppl. 51, (ed.) Lucienne Thys-Şenocak, Peeters Leuven - Paris - Bristol, 155-168.

Barlass, M., Skene, K. G. M., Woodham, R. C., \& Krake, L. R. (1982). Regeneration of virus-free grapevines using in vitro apical culture. Annals of Applied Biology, 101(2), 291-295.

Beccaria, F., \& Pretto, A. (2021). The quality of wine between innovation and tradition. a study of a changing 'Mediterranean drinking culture'. Modern Italy, 26(1), 67-78. https://doi.org/10.1017/mit.2020.75

Becker, H., \& Hiller, M. H. (1977). Hygiene in modern bench-grafting. American Journal of Enology and Viticulture, 28(2), 113-118.

Bisson, L. F., Waterhouse, A. L., Ebeler, S. E., Walker, M. A., \& Lapsley, J. T. (2002). The present and future of the international wine industry. Nature, 418(6898), 696-699.

Borsellino, V., Galati, A., \& Schimmenti, E. (2012). Survey on the innovation in the Sicilian grapevine nurseries. Journal of Wine Research, 23(1), 1-13.

Chien, M., \& Golino, D. (2006). Clean vines for healthy vineyards. Practical Winery \& Vineyard Magazine, 1-4.

Daughtrey, M. L., \& Benson, D. M. (2005). Principles of plant health management for ornamental plants. Annual Review of Phytopathology, 43, 141-169.

Fan, S., Bielenberg, D. G., Zhebentyayeva, T. N., Reighard, G. L., Okie, W. R., Holland, D., \& Abbott, A. G. (2010). Mapping quantitative trait loci associated with chilling requirement, heat requirement and bloom date in peach (Prunus persica). New Phytologist, 185(4), 917-930. https://doi.org/10.1111/j.14698137.2009.03119.x PMID: 20028471

Gramaje, D., \& Armengol, J. (2011). Fungal trunk pathogens in the grapevine propagation process: potential inoculum sources, detection, identification, and management strategies. Plant Disease, 95(9), 1040-1055.

Hartmann, H. T., \& Kester, D. E. (1990). Plant propagation: principles and practices. Prentice-Hall. pp.647

Kitamura, Y., Habu, T., Yamane, H., Nishiyama, S., Kajita, K., Sobue, T., Kawai, T., Numaguchi, K., Nakazaki, T., Kitajima A., \& Tao, R. (2018). Identification of QTLs controlling chilling and heat requirements for dormancy release and bud break in Japanese apricot (Prunus mume). Tree Genetics \& Genomes, 14(2), 1-15.

Kizildeniz, T., Mekni, I., Santesteban, H., Pascual, I., Morales, F., \& Irigoyen, J. J. (2015). Effects of climate change including elevated $\mathrm{CO}_{2}$ concentration, temperature and water deficit on growth, water status, and yield quality of grapevine (Vitis vinifera L.) cultivars. Agricultural Water Management, 159, 155-164.

Kizildeniz, T., Pascual, I., Irigoyen, J. J., \& Morales, F. (2018a). Using fruit-bearing cuttings of grapevine and temperature gradient greenhouses to evaluate effects of climate change (elevated $\mathrm{CO}_{2}$ and temperature, and water deficit) on the cv. red and white Tempranillo. Yield and must quality in three consecutive growing seasons (2013-2015). Agricultural Water Management, 202, 299-310.

Kizildeniz, T., Irigoyen, J. J., Pascual, I., \& Morales, F. (2018b). Simulating the impact of climate change (elevated $\mathrm{CO}_{2}$ and temperature, and water deficit) on the growth of red and white Tempranillo grapevine in three consecutive growing seasons (2013-2015). Agricultural Water Management, 202, 220-230.

Komínek, P., \& Holleinová, V. (2003). Evaluation of sanitary status of grapevines in the Czech Republic. Plant Soil and Environment, 49(2), 63-66.

Laucou, V., Lacombe, T., Dechesne, F., Siret, R., Bruno, J. P., Dessup, M., Dessup, T., Ortigosa, P., Parra, P., Roux, C., Santoni, S., Varès, D., Péros, J-P., Boursiquot, J-M., \& This, P. (2011). High throughput analysis of grape genetic diversity as a tool for germplasm collection management. Theoretical and Applied Genetics, 122(6), 1233-1245. https://doi.org/10.1007/s00122-010-1527-y

Lwelamira, J., Safari, J., \& Wambura, P. (2015). Grapevine farming and its contribution to household income and welfare among smallholder farmers in Dodoma urban district, Tanzania. American Journal of Agriculture and Forestry, 3(3), 73-79. https://doi.org/10.11648/j.ajaf.20150303.12

Mahenge, F. Y. (2020). The determinants of grapevine farmers' adaptive capacity to climate change in DodomaTanzania.

Moretti, S., Pacetti, A., Pierron, R., Kassemeyer, H. H., Fischer, M., Peros, J. P., Perez-Gonzalez, G., Bieler, E., Schilling, M., Di Marco, S., Gelhaye, E., Mugnai, L., Bertsch, C., \& Farine, S. (2021). Fomitiporia mediterranea M. Fisch., the historical Esca agent: A comprehensive review on the main grapevine wood rot agent in Europe. Phytopathologia Mediterranea, 60(2), 351-379. https://doi.org/10.36253/phyto-13021

Morton, L. (2012). Examples of plant material compromised by fungal pathogens. Phytopathologia Mediterranea, 51: 413.

Mullins, M. G. (1966). Test-plants for investigations of the physiology of fruiting in Vitis vinifera L. Nature, 209(5021), 419-420. 
Nicholas, P. R., Chapman, A. P., \& Cirami, R. M. (1992). Grapevine propagation. Viticulture, 2: 1-22.

Pierik, R., Tholen, D., Poorter, H., Visser, E. J., \& Voesenek, L. A. (2006). The Janus face of ethylene: growth inhibition and stimulation. Trends in Plant Science, 11(4), 176-183. https://doi.org/10.1016/j.tplants.2006.02.006

Pomarici, E., Corsi, A., Mazzarino, S., \& Sardone, R. (2021). The Italian wine sector: evolution, structure, competitiveness and future challenges of an enduring leader. Italian Economic Journal, 7, 259-295. https://doi.org/10.1007/s40797-021-00144-5

Rego, C., Nascimento, T., Cabral, A., Silva, M. J., \& Oliveira, H. (2009). Control of grapevine wood fungi in commercial nurseries. Phytopathologia Mediterranea, 48(1), 128-135.

Romeo-Oliván, A., Pagès, M., Breton, C., Lagarde, F., Cros, H., Yobrégat, O., Violleau, F., \& Jacques, A. (2021). Ozone dissolved in water: An innovative tool for the production of young plants in grapevine nurseries? The Journal of the International Ozone Association, 1-15. https://doi.org/10.1080/01919512.2021.1984203

Santa María Monasterio, E. (2005). Incidencia de Botrytis cinerea en relación con diferentesaspectos fisiológicos de la vid. In: PhD Thesis. University of Navarra, Spain.

Smart, R., Mugnai, L., \& Lane, C. (2012). International viticultural consultant's view of grapevine trunk diseases and their impact on clients. Phytopathologia Mediterranea, 51(2), 433-434.

Smart, R. (2013). Trunk diseases... a larger threat than phylloxera? Wine \& Viticulture Journal, 28, 16-18.

Sosnowski, M. R., Ayres, M. R., \& Wilcox, W. F. (2021). Cultivar susceptibility and control of angular leaf scorch in grapevine. Australian Journal of Grape and Wine Research. https://doi.org/10.1111/ajgw.12529

Stamp, J. A. (2001). The contribution of imperfections in nursery stock to the decline of young vines in California $\begin{array}{llll}\text { [Vitis vinifera } & \text { L.]. Phytopathologia } & \text { Mediterranea, 30(3), 375. }\end{array}$ https://doi.org/10.14601/Phytopathol Mediterr-1640
ards Australia (2013). AS 5588-2013 grapevine propagation material. SAl Global. https://infostore.saiglobal.com/preview/as/as5000/5500/5588-2013.pdf?sku=1674947 $\quad$ (Accessed 18 December 2021).

Waite, H., \& Morton, L. (2007). Hot Water Treatment, Trunk Diseases and Other Critical Factors in the Production of High-Quality Grapevine Planting Material. Phytopathologia Mediterranea, 46(1), 5-17. https://doi.org/10.14601/Phytopathol_Mediterr-1857

Waite, H., Whitelaw-Weckert, M., \& Torley, P. (2015). Grapevine propagation: principles and methods for the production of high-quality grapevine planting material. New Zealand Journal of Crop and Horticultural Science, 43(2), 144-161. https://doi.org/10.1080/01140671.2014.978340

Warmund, M. R., Starbuck, C. J., \& Lockshin, L. (1986). Growth, cold hardiness, and carbohydrate content of Vidal blanc grapevines propagated by hardwood vs. softwood cuttings. American Journal of Enology and Viticulture, 37(3), 215-219.

Whitelaw-Weckert, M. A., Rahman, L., Appleby, L. M., Hall, A., Clark, A. C., Waite, H., \& Hardie, W. J. (2013). Coinfection by Botryosphaeriaceae and Ilyonectria spp. fungi during propagation causes decline of young grafted grapevines. Plant Pathology, 62(6), 1226-1237. https://doi.org/10.1111/ppa.12059

Yamane, H. (2014). Regulation of bud dormancy and bud break in Japanese apricot (Prunus mume Siebold \& Zucc.) and peach [Prunus persica (L.) Batsch]: A summary of recent studies. Journal of Japanese Society for Horticultural Science, 83(3), 187-202. https://doi.org/10.2503/jjshs1.CH-Rev4

Yamane, H., Wada, M., Honda, C., Matsuura, T., Ikeda, Y., Hirayama, T., Osako, Y., Gao-Takai, M., Kojima, M., Sakakibara H., \& Tao, R. (2019). Overexpression of Prunus DAM6 inhibits growth, represses bud break competency of dormant buds and delays bud outgrowth in apple plants. PLoS One, 14(4), e0214788. https://doi.org/10.1371/journal.pone.0214788 